\title{
Leyendo el sur \\ A propósito del libro Cantes al Amorsillega de Ginés Liébana
}

\author{
Reading the south. About the book Cantes al Amorsillega by Ginés Liébana
}

BARTOLOMÉ DELGADO CERRILLO

\author{
Universidad de Córdoba \\ España
}

\begin{abstract}
Resumen. A través de los poemas del libro Cantes al Amorsillega de Ginés Liébana, haremos un recorrido por las principales coplas del cante flamenco, incidiendo en la personal interpretación que nos da el autor y aportando su relación con la significación de las formas poéticas y las imágenes con que las ilustra. Este libro es valioso para ser integrado en la educación reglada como producto cultural. Y es valioso no solo como portador de contenidos antropológicos, sociológicos, coreográficos, musicales, poéticos e históricos, sino también como compendio de los estereotipos culturales que caracterizan la identidad cultural andaluza.
\end{abstract}

Palabras clave: poesía, pintura, imagen, creación literaria

\begin{abstract}
Through the poems of the book Cantes al Amorsillega by Ginés Liébana, we will traverse the most important verses of flamenco, emphasizing the personal interpretation that the author gives us and explaining his relation with the significance of the poetical forms and the images which he uses to illustrate them. This book merit integration into formal education as a cultural product. And it is valuable not only as carrier of anthropologic, sociological, choreographic, musical, poetical and historical contents, but also as compendium of the cultural stereotypes that characterizes Andalusian cultural identity.
\end{abstract}

Keywords: poetry, painting, image, literary activity.

1 Álabe no 3- junio 2011 


\section{Introducción}

A Ginés Liébana, las llamadas de la literatura y de la pintura le sobrevinieron ya desde la adolescencia. Artista íntegro y total, está dotado de una especial predilección por el cosmopolitismo, no en vano, retomando brevemente algunos datos biográficos, pasó su infancia y adolescencia en Córdoba, ciudad donde fundó la revista poética Cántico, junto a Ricardo Molina, Juan Bernier, Pablo García Baena, Julio Aumente y Mario López, publicación que se convirtió en un auténtico baluarte lírico de una posguerra dominada por el arte social. Posteriormente se traslada a Madrid y colabora en El español como dibujante, hasta la desaparición de la revista. Viaja a Río de Janeiro, donde permanece algunos años, a París, a Suiza, a Lisboa, vive largas temporadas en Venecia y recorre en varias ocasiones toda Italia. Expone en la mayoría de estas ciudades y a finales de los años sesenta se instala definitivamente en Madrid, donde se dedica por completo a su obra creadora.

Cuando el poeta empieza a escribir, los temas, los gustos, las visiones... se agolpan anárquicamente, pero creo que hay un momento en el que descubre algún tema concreto, un modo de orientar sus pensamientos y los versos e intenta desarrollarlos. Ese es el caso de Ginés Liébana. A él le ha sucedido con el flamenco, no solo con el flamenco como tema, sino también con todo lo que sugiere: la sensualidad de un baile, el sentimiento de la tierra, el ritmo roto, diletante y acompasado de los cantes, la emoción que dilata el sentimiento... y siempre la porfía del poeta:

\footnotetext{
No me pidas que baje al lugar donde los otros no se atreven. En mis descendimientos cumplí cien lenguas con desplante, Y en mis pesares no hay más allá que lo mío.
}

(Liébana, 2009: 23)

Al igual que Ginés, otros poetas, cofundadores del grupo Cántico, también fueron pintores: Pablo García Baena, Mario López y Julio Aumente; quizá por eso, destaca en sus versos la relevancia de las imágenes, pero no de cualquier imagen, sino de esas que se construyen con símbolos y palabras; en el caso de este libro de poemas, ha concentrado muchos de sus esfuerzos en la búsqueda de esa imagen lograda y 
deslumbrante. En definitiva, podríamos decir que estamos ante la pintura literaria de Ginés Liébana, salpicada por doquier del sentimiento del sur.

El sentimiento de la tierra, del paisaje, es, para Ginés, una vivencia íntima tan reconfortante que hace al artista eliminar la ansiedad. En opinión del crítico de arte Miguel Clementson (2011: 5), "el paisaje es el que marca la propia presencia del artista en el mundo, que debe leer en el manuscrito de la naturaleza y a la vez desarrollar sus potencialidades específicas, con objeto de generar finalmente la plasmación de su privativo paisaje interior". Así también ocurre con esta obra que comentamos. Que en pintura existe un determinismo regional, es algo que está fuera de toda duda. Por poner un ejemplo, Cézanne, a pesar de su racionalismo, no pudo escapar a su condición de hombre nacido en Aix-en-Provence, y sobre la raíz geométrica de sus cuadros, siempre flotó el cielo de su tierra natal (Delgado Cerrillo, 2002). En esta misma línea se expresa, en el prólogo del poemario que nos ocupa, el dramaturgo Francisco Nieva, amigo personal del artista, cuando afirma:

La poética dibujística y pictórica de Ginés Liébana concibe el universo como si todo él fuera andaluz. Cada una de sus obras - de mayor o menor empeñoequivale a una de esas misteriosas e irracionales "coplas" en que el espíritu andaluz aparece divinamente trastornado, fino y neurótico, imbuido de nostalgia y de fantasía. (Liébana, 2009: 7)

El propio Ginés reconoce, a través de sus versos, la especial intensidad con que nos marca en todos los aspectos la tierra en que nacemos. Liébana activa en toda circunstancia la presencia de su origen, por mucho que haya viajado y se hubiese podido influenciar de determinadas escuelas pictóricas en el camino. Para él, lo más excelso es el pueblo. Hay que observar a las gentes que constituyen la presencia humana del lugar, escucharlas atentamente cuando hablan. De este caudal, precisamente, nace toda la poesía popular de Andalucía. El artista debe estar atento a estos registros.

Las técnicas utilizadas son muy motivadoras: los valores visuales del verso, la imaginación desbordada, la metáfora, los sintagmas nominales, las repeticiones sintácticas y la anáfora, la subordinación, todo ello hace que, como poeta, no se sienta condicionado en su proceso creativo, escribiendo poemas muy sugerentes. Destaca el uso audaz de la metáfora, como una actitud filosófica que supera los estrechos límites a 
los que la condenan los áridos catálogos de la retórica tradicional, así como el uso de personificaciones que adquieren en su contexto gran valor expresivo. Su intención no es otra que traducir en imágenes extrañas coplas de un perdido cancionero andaluz.

En estos versos, el poeta sabe penetrar hasta la médula para consonar cante y sentimiento, canción y poesía, palabra e imagen. Y esto es así porque Ginés es un gran conocedor del alma humana, como lo demuestran sus obras pictóricas, sobre todo los ángeles, de formas inagotables y siempre expresivos y sensuales, y los retratos, la mayoría de amigos y personajes del mundo de la música, la literatura, la política... donde no descuida el realismo, pero contrastándolo con imágenes superpuestas surrealistas que aportan una mejor definición del retratado.

Además, los poemas de este libro ponen de manifiesto su interés por el lenguaje, su inagotable capacidad para crear unos neologismos muy personales, su clara preferencia por el singular y su persecución implacable en contra de los plurales: "El plural es burdo, diluye la esencia, vulgariza la expresión" (Liébana, 2008). Son, por tanto, realmente escasas las palabras en número plural que podemos encontrar en el poemario que nos ocupa.

Su obra literaria ha ido adquiriendo dimensión con el transcurso de los años. El aspecto formal y la pauta rítmica cobran densidad en sus versos, producto del constante trabajo con el lenguaje, hasta el punto de que podríamos afirmar que su trayectoria y sus obras literarias evolucionaron hasta encontrar el equilibrio entre la búsqueda interior y las múltiples experiencias del mundo externo. Leyendo sus versos podemos decir que, tal vez, la forma más natural de la poesía es aquella que comunica al habitante con su paisaje, con su tierra, con su folklore; poesía y emoción se fertilizan en la realidad de sus poemas y no en la fantasía libresca. La lectura de sus versos necesita que respiremos diferente porque su poesía es la puerta de entrada a un mundo, comprenderlo es aprender a mirar, a tocar y sentir lo que nos rodea como si fuera la primera vez.

Los poemas y las ilustraciones de estos Cantes al Amorsillega presentan un prodigio metafórico escrito en imágenes que buscan el alma de lo poético. Hablar sobre el sentimiento del sur que late en este poemario es asistir al fascinante proceso de 
reconstrucción de la memoria, como pasar en un álbum imaginario las hojas del tiempo y con ellas representar serenamente cuanto en él acaeció, cuantos sentimientos fue posible experimentar, cuantos misterios quedaron calladamente sin descubrir. Como anticipa el propio autor, a modo de subtítulo, en una inicial dedicatoria, estamos ante "las claves para consonar la compasión y el grito en la zanja de los columbarios flamencos" (Liébana, 2009). Para él, la vida consiste en ir llenando la nada de hermosura. Como en la pintura, el propio concepto de belleza y el sentimiento, como fundamentos creativos, enriquecen la estimación de la poesía.

Para ilustrar lo que venimos afirmando, haremos, a continuación, un breve recorrido por algunos de los poemas de esta obra, tomando como punto de referencia las alusiones directas que hace el poeta a los diferentes palos y coplas del cante flamenco, así como el entronque de estos versos con el sentimiento del sur.

\title{
RETORNO
}

\author{
La habanera, en el rincón de un gesto trenzado \\ con el salto-paso del pájaro, \\ se pavonea con disfraz de pluma \\ en el cerro de Andévalo con la danza de espadas. \\ Buscadora de culpa, va de madre por la corredera, \\ al convento de las carmelitas de castigo. \\ Al entrar por el arco de la hermética casa \\ su llanto-trino picotea las migajas del mantel del cuervo \\ en el aire que silba a la luna empolvada. \\ Anudada va la habanera en la cuerda de los braceros \\ que trasladan arena y derraman lágrimas granizas.
}

(Liébana, 2009: 18)

De origen cubano, de ritmo cadencioso y compás binario, la habanera se considera una de las formas primitivas de la cual derivó el tango. Para el novelista Pío Baroja (2006), la habanera es, esencial y fundamentalmente, una confidencia de nostalgia, una íntima confesión de lejanas añoranzas, que solo se hace entre los amigos, que está hecha para abrazarse y bailar, como el tango, su heredero. Ginés nos la retrata como una figura inquieta y ligera, que traspasa todas las paredes, y remata esta visión con dos versos finales de claros tintes sociales. 


\section{VESTIDO DE OASIS}

Los verdiales son el fandango del pueblo

y la tristeza, para salvar su aislado desnudo, no acude a la celebración.

El sol enfadoso con llama en las espuelas le dio sitio escaso

en la cabalgata funérea de la noche.

Ceder el paso enamorado a un canto sin juicio

Silencia la angustia del tablao.

En la antesala el placer perfuma su voluntad para comprar un trino.

Con cinco palos y una alambrada se protege la mínima unidad del embeleso.

(Liébana, 2009: 21)

Considerado el prototipo del fandango campesino, los verdiales son un cante de ascendencia morisca, que no ha terminado de aflamencarse hasta la fecha y mantiene claramente todas sus raíces folclóricas. Ginés, mediante esa magnífica metáfora del primer verso, nos introduce en el ambiente festivo, nocturno y danzarín de este palo, que es cante y baile al mismo tiempo.

\section{GAVILLAS PAJIZAS}

La Petenera, recién salida de la cautividad de la marea, le puso luto al frasco oscuro del cante.

Con una garzota en el ocaso, vestida de modisto, entallada en respingos, harta de lunares, porta un paquete entero de plumas negras.

Esta hembra, enteramente mistiflora, con la taurina peina de la Isla, sigue consensuada, corta de puesto, en la estética de la mortaja entre lámparas. Esta estocástica jamás llegó a pensar que sería beneficiada por un diluvio de lágrimas en su sepelio.

(Liébana, 2009: 22)

Cante difícil, de entonación pausada, solemne, emotiva y a veces sentenciosa, revestido siempre de leyenda y al que se le ha atribuido que, para los gitanos, ha tenido siempre "mal fario". También aquí, el poeta nos hacer ver cómo la petenera se ha encarnado en la figura de una mujer, portadora de plumas negras, retomando la 
tradición que concede a este cante un tono triste y melancólico, interpretado de forma lenta y sentimental.

\section{SOLICITA PLAÑIDO}

Un devoto en picar la piedra filosofal del cobre exhumó a la taranta.

In extremis, salió letrada del Eremitorio.

¿Qué se trae esa trepadora que no sabe dar contento al deleite? La opción de penitencia lleva eje y duende dramático.

La alarma anuncia la campana cuando la travesera se derrumba.

No me pidas que baje al lugar donde los otros no se atreven.

En mis descendimientos cumplí cien lenguas con desplante.

Y en mis pesares no hay más allá que lo mío.

Lo que me está ocurriendo enciérramelo

en el estuche con la guitarra de Satirio.

(Liébana, 2009: 23)

Este cante es, sin duda, el que funciona como patrón musical de los cantes de las minas. La taranta minera está impregnada del ambiente fatigoso de las galerías y socavones de las minas; es un cante sobrio, de tercios cortos y angustiosos. La referencia a las duras condiciones de trabajo en las minas están apuntadas en estos versos, en que el poeta dialoga con la taranta: "No me pidas que baje al lugar donde los otros no se atreven".

\section{OTORGO}

La mandolina de la lágrima pasa por la estrecha compuerta de la Debla. Por la calle del Duende irrumpe el confidente filosófico. La tarde se expresa en el trago amarillo de los Moriles. No añadas más destrozos al castigo y vete de "sueños". No rechaces al dios que ajusta sus estribos al herido costado. Recuérdame que te compre dignidad para que te mejore la figura, que el querer no necesita parpadeo para elevar el costal de su estatura onfálica.

(Liébana, 2009: 25)

En opinión de Hipólito Rossy (1998), la debla es incluso anterior al flamenco, estimando que de todo el cante jondo, ninguno tan angustioso, tan desolado como la 
debla. Es el canto del hombre que ha conocido todas las claudicaciones, todas las humillaciones, amarguras y ruindades de la vida, que vegeta sin esperanzas de redención. El léxico de este poema gira en torno al campo semántico de la tristeza lágrima, destrozos, castigo, herido costado- y convive con las referencias al duende y al vino de esta tierra.

\section{RENGLÓN AFILADO}

En una trona iba la soleá con tres barandales.

En uno llora glicinias.

En otro, a mares.

$\mathrm{Y}$ al tercer barandal, al pasar por tu puerta,

le entran las calambres.

Y cuando la seguiriya salía de la boca de María Borrico,

a cuartitos se nos partía el corazón.

Entonces se cantaba latín en la Misa.

La polifonía no estaba arrinconá.

El baile se arrastraba,

se cantaban letras salidas de los columbarios escritos en los mármoles.

En las tabernas se daban zorzales enharinaos y habas corchás.

Antonia, la viuda, con gentil postura y oposición paterna, con los dedos de sus pájaras manos metía la punta del zapato para coincidir con los pasos sentaos.

Debajo de la falda iba su dueño.

(Liébana, 2009: 27)

Se trata de uno de los estilos básicos del cante flamenco. Las letras de sus coplas responden a una temática muy amplia, desde lo intranscendente a lo trágico, pero siempre con rebosante humanidad, destacando sus alusiones a la vida, al amor y a la muerte. Mediante un lenguaje muy popular y aderezado con algunos andalucismos ("a cuartitos", "arrinconá", "zorzales enharinaos", "habas corchás”..) el poeta nos introduce en el mágico mundo del ambiente tabernario, donde triunfaban la soleá y la seguiriya, mientras sientes cómo te late el corazón al compás de la guitarra y al son de los cantes.

\section{VINO CORVILLO}

La seguiriya emigra por el monte cerrado.

Si me odiaras, lo harías.

El débil mecanismo espía para rozarse. 
Entre piedras mojadas y ríos vacíos se acerca al compás.

Habla en violeta y entrega la batuta, la presta por minutos y la clava en romero seco.

Los pesares exigen al relicario de la espina sin romper el salero oscuro de la Rondeña.

(Liébana, 2009: 30)

Cante dramático, fuerte, sombrío y desolador, sus letras tristes, sentimentales, suelen reflejar la tragedia humana. Para Manuel Machado (Blas Vega, 1982), la seguiriya era el quinto extracto de un poema dramático. En efecto, se trata de un cante trágico, dolorido, que expresa la desgracia humana en toda su extensión. Es la rebelión del albedrío humano, expuesta con la quejumbrosidad extrema del jipío que nace ante una situación límite. Mediante una sucesión de imágenes, donde hacen acto de presencia el oxímoron (contradicción entre dos vocablos que, aparentemente, se excluyen, pero a los que el contexto hace compatibles: "piedras mojadas y ríos vacíos") y la sinestesia (comparación-relación entre dos sentidos: "habla en violeta"), Ginés nos invita a respirar el aire de este cante.

\section{La poesía pictórica de Ginés Liébana}

Si pretendemos calibrar adecuadamente el binomio al que hace alusión la expresión "poesía pictórica", debemos partir del valor artístico que poseen estos versos, que, a la postre, se resume en dos elementos, a saber, el matiz y la fuerza expresiva. En la valoración artística de cualquier producción de este tipo advertimos dos fases bien diferenciadas, a saber, la estructura interna y la forma expresiva externa. La primera es una fase consustancial con el estilo y la personalidad de Ginés, y se puede definir como la manera particular de sensibilizar las ideas; entran en acción todos los elementos subjetivos del poema -categorías estéticas-y las facultades anímicas del poeta: poder inventivo, matización figurada e imágenes propias, tradición culta o popular... Sin olvidar que la estructura armónica del verso pide un contenido de imágenes y emociones. La forma expresiva externa es la segunda característica del valor artístico de un poema. En todo momento, el poeta ha de llevar a cabo el gobierno de su lenguaje en la precisión constructiva del verso, en el ritmo, en la abundancia, color y propiedad de los vocablos, en los neologismos y en todo su léxico... 
A la luz de estas líneas, podemos afirmar que el uso del lenguaje poético que hace Ginés tiene múltiples fines: para despertar emociones, para embellecer el lenguaje y crear la belleza, para intensificar y poner énfasis, para evocar una escena, un recuerdo, una memoria, para conseguir mayor armonía, para crear dinamismo, en definitiva, para jugar con el lenguaje e invitar al lector a participar en ese juego literario.

No hay que olvidar las ilustraciones de los diferentes poemas. Dieciséis de los treinta y tres poemas que componen esta obra están ilustrados con imágenes del propio Liébana, la mayoría ángeles y bailaoras. Y es que a Ginés las vistas panorámicas vacías, sin figuras, no le interesan. Introduce constantemente personajes que constituyen arquetipos del comportamiento humano, de la voluntad, de la ira, del amor, del deseo... recreándose así en un mundo imaginario extraído del ámbito del delirio o de los dominios del subconsciente, de una gran belleza plástica. En estas ilustraciones el mundo se torna teatro y la ficción se convierte en posible representación. Lo absurdo, el ámbito de lo irracional, las imágenes oníricas, lo mágico, lo misterioso, lo hermético, lo insólito... tienen cabida en este cosmos privativo que fluctúa entre el teatro del absurdo de Valle-Inclán y el drama shakespeariano. Liébana nos habla en estas imágenes de la zozobra de la humanidad, de una suerte de destino universal de la especie, ácidamente trascendido. Por eso, en ocasiones, las figuras se descomponen o mimetizan en el paisaje, desintegrando su carnalidad en el espacio o engastando su concreción física en la propia orografía mineral del cuadro.

Nadie mejor que este pintor-poeta para poner en relación directa la imagen hija de los trazos del artista y la que sabe recrear con ese lenguaje culto y popular al mismo tiempo. Se trata, pues, de un texto doble, susceptible de una recepción estética conjunta, lectura de la que se benefician ambas partes, pero igualmente susceptible de una recepción individual, de la que ninguna de ellas sale perjudicada puesto que ambas lecturas no se subordinan entre sí, palabras que resumen nuestra postura respecto a la convivencia fructífera de ambas artes.

Cumplidos ya los noventa años, sigue sin agotar aún su capacidad de sorpresa para el amor y lo existente. Reconoce que su mayor capital es el entusiasmo, la clave que activa cada día su tránsito por el mundo, y que ese derroche de vigor que despliega 
llega a contagiar a la gente. Ginés tiene una visión cósmica de la existencia -muy oriental, por cierto-, en la que todo confluye en cualquier circunstancia y, por tanto, igualmente concurre en la práctica de la pintura, que se convierte en un constante diálogo entre el artista y los objetos que habitan el espacio circundante. La pintura es, para él, una manera de vivir; el artista sintetiza todo cuanto hay a su alrededor, constata esas vivencias, aquellas que han sido manifiestamente interiorizadas, materializándolas en un soporte físico a través de la dinámica plástica.

La pintura va acompañada de todas las demás cosas; nunca va sola. Cada afirmación del artista, cada obra, confirma su vivencia. Para Ginés la propia vida es tan ficción como la pintura. La función del pintor reside en aprehender la voluntad de ser de las cosas, sin que considere del todo necesario constatar plenamente la disposición de forma de estos objetos. De igual manera que la vida se percibe como un torrente en continuo movimiento, la pintura se ha de considerar así también. Nada está acabado; por eso, Ginés retoca constantemente sus trabajos. La misión del pintor estriba en rescatar de lo invisible las ideas que desean ser nombradas, pues en el espacio, en el cosmos, existen barreras invisibles que nos impiden ver la esencia real de las cosas.

En realidad, podemos decir que todo lo que hay en estos Cantes al Amorsillega es poesía, y todo es imagen, recordando aquella vieja máxima sobre la conjunción de las artes: Ut pictura poiesis (la poesía es como la pintura). La relación entre pintura y poesía ha tenido gran desarrollo en el pensamiento literario occidental. Recordemos que el concepto de Ut pictura poiesis fue puesto en circulación por la filosofía griega, para la cual, la poesía cobra estatuto de imagen con palabras, representación visual con palabras y sonidos que crea percepciones y símbolos. Estas relaciones entre artes cobran un lugar especial en un texto como este libro de poemas que convoca relaciones interartísticas.

Así también Tiziano bautizó las pinturas como "poesías”, entendidas como obras concebidas para deleite de los sentidos ajenas a interpretaciones simbólicas o moralizantes. Las pinturas mitológicas de Tiziano pertenecen a un género que permitía al pintor emular a los poetas clásicos y demostrar la veracidad de esa hermandad entre poesía y pintura que constituía uno de los pilares de la teoría humanista de las artes. 
Como se sabe, esta afirmación según la cual, una poesía debe ser como una pintura, procede de un texto de Horacio que se utilizaba para justificar la más estrecha relación entre las diferentes artes: completamente por fuera de la intención original de su autor, se llegó a plantear, incluso, que la belleza de una obra poética dependía de la cantidad de cuadros que pudieran sacarse de ella (Fernández Uribe, 2008: 188-189).

En su breve ensayo Laocoonte, el escritor alemán Gotthold Ephraim Lessing (1977) argumentaba, de forma brillante y razonada, que la literatura y las artes plásticas utilizan recursos distintos para provocar la catarsis en el espectador, aduciendo que mientras que los cuerpos y sus propiedades visibles son los objetos apropiados de la pintura, las acciones son los objetos propios de la poesía.

Desde entonces, y coincidiendo con la irrupción del romanticismo, la reflexión estética ha explorado distintos caminos y tendencias -desde el idealismo hasta las primeras y últimas vanguardias del siglo $\mathrm{XX}$, pasando por el existencialismo, el marxismo o el psicoanálisis- para intentar explicar cómo y por qué un poema, una pintura, una novela, una escultura, una obra de teatro, o incluso una película, son capaces de trastornarnos, de sacudirnos y hacernos experimentar ese tipo de disfrute o emoción, a caballo entre la experiencia amorosa y la experiencia mística o trascendental, que convencionalmente se denomina estética (Solana, 2003).

Y es que las civilizaciones se revelan más o menos abiertamente a través de sus realizaciones artísticas, que no solamente aspiran a un ideal supremo, sino que también proporcionan al completo las formas de vida, de ser y de sentir. El arte siempre se refiere a los productos del hombre; se trata de objetos que adquieren una existencia autónoma y permanecen ligados al estricto mundo de las ideas (Delgado Cerrillo, 2002).

En cierto modo, podríamos decir que la literatura y las artes plásticas -y en este sentido también la música- traducen y universalizan experiencias, sentimientos, ideas y conocimientos. Eso es precisamente lo que hace Ginés Liébana en este libro. Las palabras son signos de las cosas, y palabras e imágenes traducen, en la medida en que interpretan, esos signos de las cosas. Porque interpretar, ejercer de hermeneuta de la realidad, es traducir. En este sentido, estos Cantes al Amorsillega de Ginés Liébana, 
desde las atalayas de la poesía y la pintura, traducen el mundo a un lenguaje nuevo a través de metáforas, imágenes realistas y surrealistas, fábulas y sensaciones. Lo ensanchan, lo recrean, lo transforman y lo aniquilan; manteniéndolo, de este modo, en un estado de perpetua generación. Leyendo los versos de este poemario, en parangón con las ilustraciones correspondientes, se percibe un trabajo silencioso, de búsqueda y de afirmación de una manera propia y personal de sentir la poesía y la pintura.

El profesor y poeta Diego Martínez Torrón (2002) ha estudiado con detenimiento la poesía de Ginés Liébana, si bien, sus últimas obras, donde se manifiesta su tinte más personal, con grandes dosis de humor, ironía y surrealismo, sin olvidar un intenso sentimiento del sur, están faltas de un análisis más profundo. Con este estudio hemos pretendido cubrir en parte esa laguna, a sabiendas de que más adelante aparecerán nuevas obras poéticas, como la que anuncia el propio Ginés para la primavera de 2011, mientras se está redactando este artículo, y que lleva por título Cautivo placer acorazado, a la que en un futuro próximo dedicaremos también un detenido análisis.

Por su parte, el profesor y crítico literario Antonio Garrido se expresa en estos términos en el prólogo de la obra que comentamos:

Sea este libro un laberinto de bellezas y un cóctel de muy alta graduación que nos lleva a dos fuentes, la del conocimiento y la de la eterna juventud, porque en el jardín sagrado de la palabra tenemos nuestro asiento, el escabel precioso de marfiles que Ginés nos regala en cada página que nos lleva al asombro y al arrobo de la música de la pandereta en la plaza y del órgano en la catedral y del violín en la sala de conciertos para que todo sea columna gigante de cante verdadero y baile que nos vuelve locos de atar por tanta hermosura concentrada en el principio del canto de todas las cosas y de la línea de dibujo inocente que se hace rocalla en los retablos de la tierra divina. (Liébana, 2009: 6).

La periodista gallega Fabiola Martínez Vega nos ha dejado esta breve y acertada etopeya de Ginés Liébana:

El que no conoce a Ginés no sabe lo que es el arte ni la vida y difícilmente entenderá lo que es la esencia del ser humano. Una tarde con él es como hacer un doctorado en la mejor universidad del mundo -la experiencia de la vida-, el plus que tienen las canas tan en desuso en una sociedad que pretende dar valor solo a la juventud, olvidando que el valor real es la vida misma. Si el pintor es bueno, el poeta lo es más, cada uno de sus poemas... se puede releer cien veces y las cien 
será diferente. Juega con el agua como fuente de vida, juega con el amor como motor del mundo y ese juego es serio, no para niños, aunque a pesar de los años todos seguimos siendo los niños que fuimos. "Ginés Liébana, de profesión activo", como él se define, es el personaje que España debería conocer y venerar como el último bohemio de una generación que sobrevivió a una guerra y que pocos han sabido superar con la fuerza de la vida que a Ginés le sigue haciendo trabajar con más fuerza cada día. (Martínez Vega, 2009).

Creo no equivocarme si afirmo que Ginés Liébana entendió siempre la poesía y la pintura- como un acto de la voluntad antes que un regalo de la inspiración, razón por la que él no entiende de ritos, como no sea el de ponerse delante de un papel $-\mathrm{o}$ de un lienzo- y de mirar hacia adentro para extraer una vivencia sedimentada, una rosa incorrupta, una paisaje añorado, un dolor, un cante, un gozo, una sombra que ha medrado en el vértigo y la noche. Y es que la lengua no solo se escucha, también se ve, se dibuja, se talla, se esculpe, se filma, se canta... Con ella se sueña, se trabaja, se promulgan leyes, se reza, se enamora... Por eso, su uso no puede constreñirnos por falta de recursos o destrezas; el empleo creativo del lenguaje debe conducirnos, entre otras cuestiones, a la percepción de lo distinto, a la estimulación de lo innovador, para lo cual es necesario que la lengua se conciba como un conjunto en el que caben producciones múltiples. La lengua es un producto coral que los individuos enriquecen o empobrecen. (Reyzábal y Tenorio, 1994).

\section{Conclusión}

Nuestra inteligencia, nuestra cultura, incluso nuestra convivencia están hechas de palabras, y precisamente somos capaces de simbolizar porque tenemos palabras. Por tanto, la capacidad de razonar sobre la realidad solamente se adquiere con un buen dominio lingüístico. El poeta ve la realidad quintaesenciada, pues vive entregado a sí mismo. Sabe muy bien que detrás de las formas externas existe otra cosa y aprisionar ese algo misterioso no es tan fácil de expresar como la luz y el color. Los sentidos todos del poeta adquieren una sensibilidad excepcional, pues ve en la naturaleza relaciones misteriosas que los demás no perciben. Ginés Liébana es un poeta dotado de una gran sensibilidad, honesto, que sale al encuentro de la vida por derecho.

Sabemos que la literatura en general y la poesía en particular tienen que competir hoy con los trepidantes avances que nos ha traído el nuevo siglo, hay incluso 
algún iluminado que ha vaticinado el fin de los libros, precipitado por el impetuoso empuje de las nuevas tecnologías y las comunicaciones planetarias. Ante este panorama, bueno será recordar aquí algunas de las palabras liminares de Rubén Darío:

La gritería de trescientas ocas no te impedirá, Silvano, tocar tu encantadora flauta, con tal de que tu amigo el ruiseñor esté contento de tu melodía. Cuando él no esté para escucharte, cierra los ojos y toca para los habitantes de tu reino interior... (Rubén Darío, 1999: 85). 
Anexo. Algunas ilustraciones del pintor-poeta Ginés Liébana incluidas en su obra Cantes al Amorsillega.

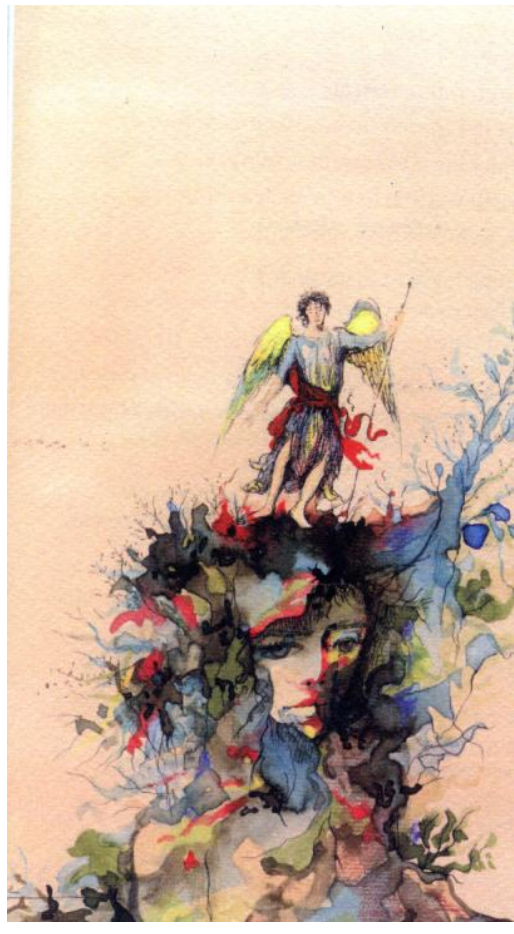

Ilustración nº 1

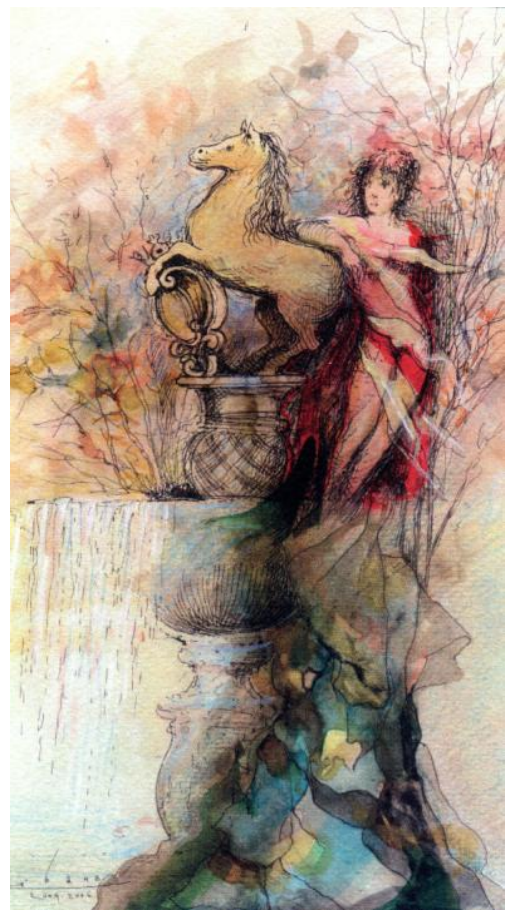

Ilustración $n^{0} 2$

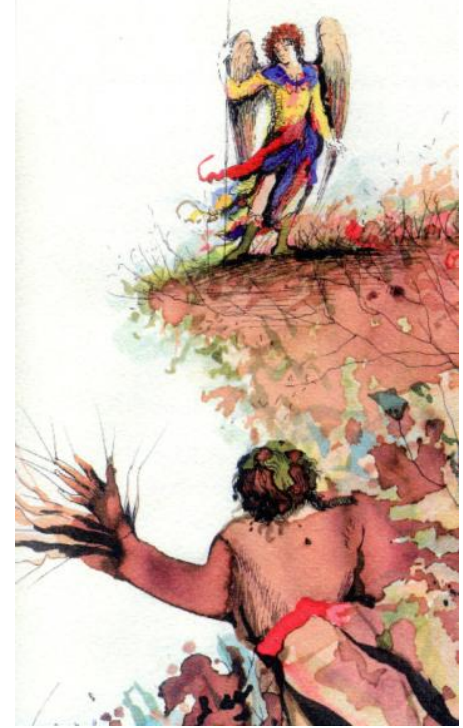

Ilustración n०3

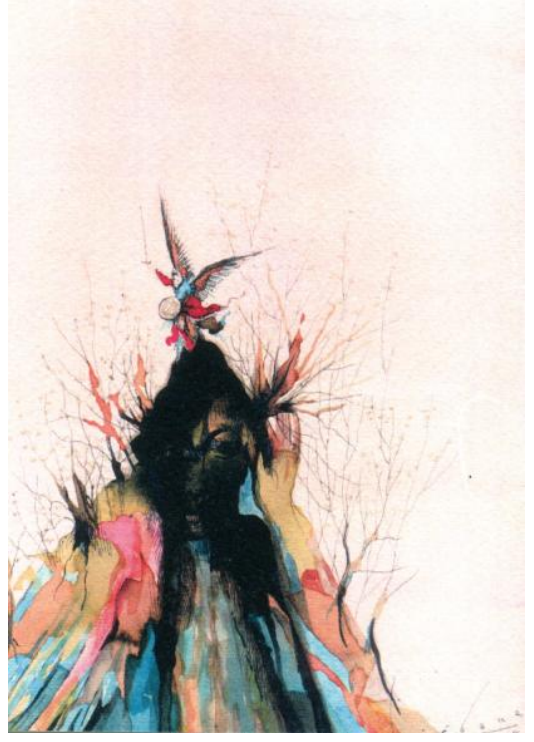

Ilustración no 4

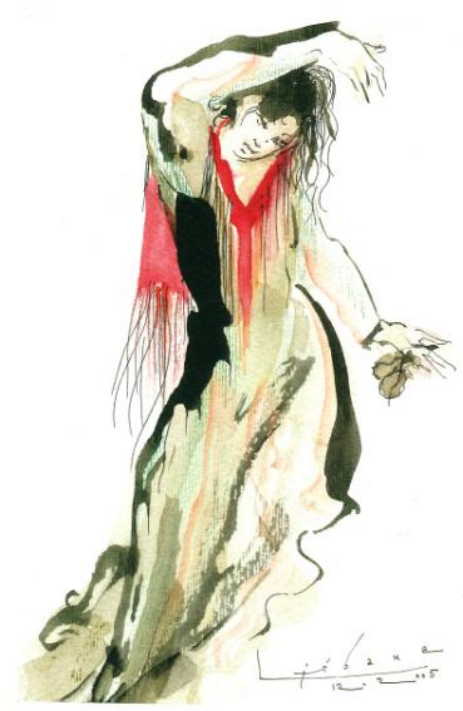

Ilustración no 5

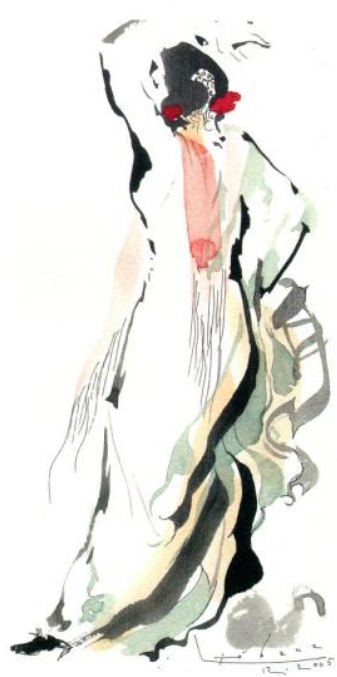

Ilustración no 6 


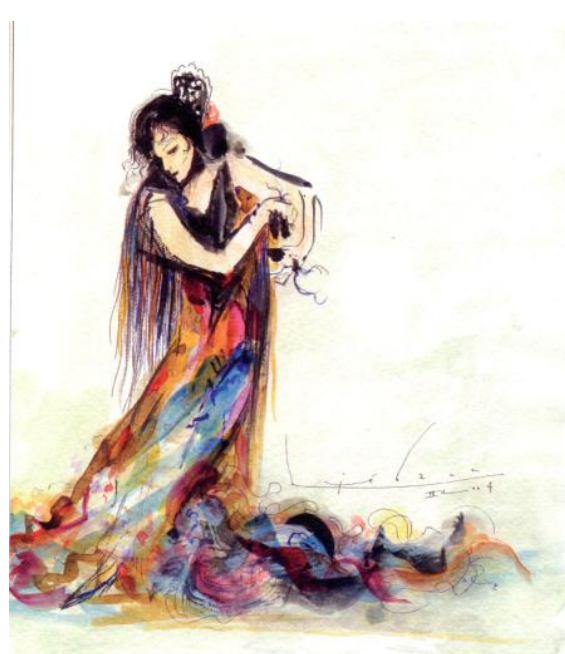

Ilustración no 7

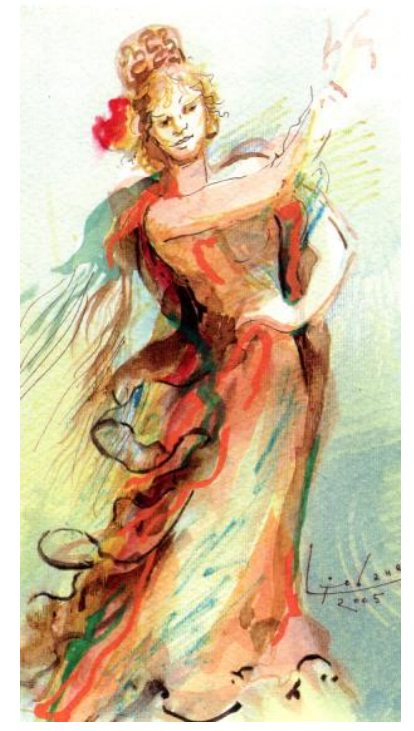

Ilustración no 8

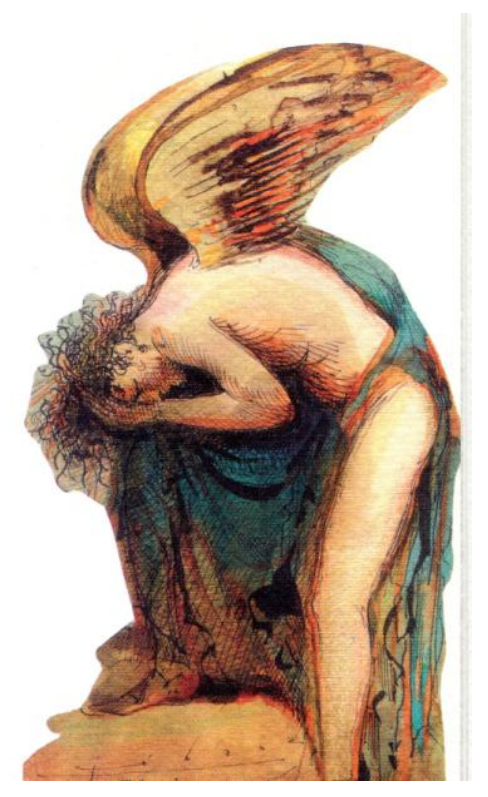

Ilustración no 9

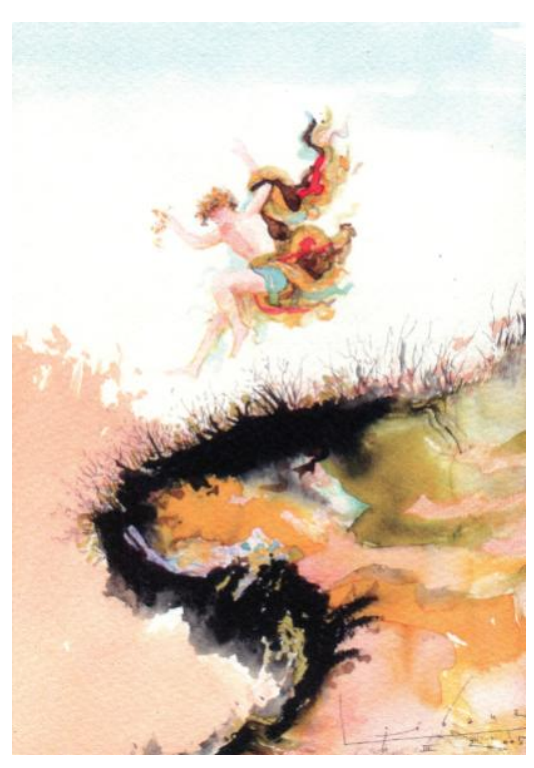

Ilustración no 10 


\section{Referencias bibliográficas}

\section{A) De las ilustraciones}

Ilustración no 1.- LIÉBANA, Ginés. (2009). Cantes al Amorsillega. Córdoba:

Diputación de Córdoba (Área de Cultura), pág. 28.

Ilustración no 2.- LIÉBANA, op. cit., pág. 48.

$>$ Ilustración no 3.- LIÉBANA, op. cit., pág. 58.

$>$ Ilustración no 4.- LIÉBANA, op. cit., pág. 14.

$>$ Ilustración no 5.- LIÉBANA, op. cit., pág. 16.

Ilustración no 6.- LIÉBANA, op. cit., pág. 34.

> Ilustración no 7.- LIÉBANA, op. cit., pág. 36.

$>$ Ilustración no 8.- LIÉBANA, op. cit., pág. 40.

$>$ Ilustración no 9.- LIÉBANA, op. cit., pág. 25.

Ilustración no 10.- LIÉBANA, op. cit., pág. 20.

\section{B) Del texto}

Baroja, P. (2006). Desde la última vuelta del camino. Vol. III. Colección Tiempo de Memoria (edición del Cincuentenario Pío Baroja 1956-2006) Barcelona: Tusquets Editores.

Blas Vega, J. (1982). Magna antología del cante flamenco. Madrid: Hispavox. Se trata de una referencia que hace José Blas Vega de Manuel Machado en el libreto que acompaña a los diez discos compactos que componen esta antología.

Clementson Lope, M. (2011). Liébana y Dalí. Córdoba: Servicio de Publicaciones de la Universidad de Córdoba (Vicerrectorado de Estudiantes y Cultura).

Darío, R. (1999). Prosas profanas y otros poemas (1896-1901). Edic. de Álvaro Salvador. Madrid: Akal.

Delgado Cerrillo, B. (2002). En torno a la pintura de Sánchez Collado. Obtenido el 6 de marzo de 2011 desde: http://esanchezcollado.blogspot.com/

Fernández Uribe, C. A. (2008). Concepto de arte e idea de progreso en la historia del arte. Medellín: Editorial Universidad de Antioquia.

Lessing, G. E. (1977). Laocoonte o sobre las fronteras de la poesía y la pintura. Trad. Eustaquio Barjau. Madrid: Editora Nacional.

Liébana, G. (2008). Ginés Liébana, entre imágenes. Obtenido el 5 de marzo de 2011 desde http://paginaoficialdeginesliebana.blogspot.com/2008/12/gins-libana-entre-imgenes.html

Liébana, G. (2009). Cantes al Amorsillega. Córdoba: Diputación de Córdoba (Área de Cultura).

Martínez Torrón, D. (2002). La poesía de Ginés Liébana, en Boletín de la Real Academia de Córdoba de Ciencias, Bellas Letras y Nobles Artes, 142, 319-324. 
Martínez Vega, F. (2009). Ginés Liébana, un artista con "dos cejas". Obtenido el 6 de marzo de 2011 desde: http://www.elsemanaldigital.com/blog.asp?idarticulo=96874\&mes $=5 \&$ ano $=2009$

Reyzábal, M. V. y Tenorio, P. (1994). El aprendizaje significativo de la literatura. Madrid: La Muralla.

Rossy, H. (1998). Teoría del Cante Jondo. Barcelona: Credisa.

Solana, M. (2003). Ut pictura poiesis, en El Trujamán. Revista diaria de traducción (Centro Virtual Cervantes). Obtenido el 8 de marzo de 2011 desde: http://cvc.cervantes.es/trujaman/anteriores/marzo 03/18032003.htm

(Artículo enviado: 09-03-2011; revisado: 25-05-2011; aceptado: 08-06-2011) 